\title{
STRATEGI DIPLOMASI PEMERINTAH INDONESIA DALAM MENINGKATKAN KUNJUNGAN WISATAWAN ARAB SAUDI PADA TAHUN 2014-2016
}

\author{
Elda Agustina Qomaria, Agung Yudhistira Nugroho \\ Universitas 17 Agustus 1945 Jakarta \\ nengeldaa@gmail.com,aijin_agung@yahoo.com
}

\begin{abstract}
ABSTRAK
Sektor Pariwisata adalah salah satu sektor yang mengalami peningkatan sangat pesat dalam hal penerimaan devisa setelah komoditi minyak dan gas bumi. Sehingga Pemerintah Indonesia yang dipimpin oleh Presiden Joko Widodo memberikan tugas kepada Kementerian Pariwisata untuk giat mencari strategi dan upaya untuk meningkatkan arus wisatawan mancanegara, khusus dalam penelitian ini wisatawan Arab Saudi karena Arab Saudi adalah negara pengunjung terbesar sekitar 87,33\% dari total kunjungan wisatawan Timur Tengah.

Sehingga rumusan masalah penelitian ini adalah bagaimana strategi yang digunakan Pemerintah Indonesia untuk meningkatkan kunjungan wisatawan Arab Saudi ke Indonesia pada tahun 2014-2016. Penelitian ini bertujuan untuk mengetahui strategi diplomasi yang digunakan Pemerintah Indonesia meningkatkan wisatawan Arab Saudi.

Strategi yang digunakan Pemerintah Indonesia dalam hal ini Kementerian Pariwisata yaitu Diplomasi yang digunakan oleh Pemerintah Indonesia dalam meningkatkan wisatawan Arab Saudi dengan menggunakan Paradiplomasi dan Multi Track Diplomacy: 9 Track Diplomacy yang lebih fokus pada track Pemerintah, track non-Pemerintah, track bisnis, track warga negara, track penelitian/pelatihan dan pendidikan serta track media. Dari kegiatan yang dijalankan Kementerian Pariwisata yaitu Pameran, Misi Penjualan/Sales Mission, Familiarization Trip (FamTrip) dan Festival. Penerapan strategi Pemerintah Indonesia dalam meningkatkan kunjungan wisatawan Arab Saudi telah dilakukan dengan baik. Pemerintah Indonesia menjalin diplomasi secara efektif untuk menciptakan saling pengertian dalam menjembatani informasi tentang pariwisata Indonesia serta melaksanakan kegiatan-kegiatan yang meningkatkan kunjungan wisatawan Arab Saudi.

Metode penelitian yang digunakan yaitu deskriptif kualitatif dengan menggunakan teknik wawancara dan liberary research dengan panduan interview staff khusus kajian Timur Tengah Kementerian Pariwisata. Berdasarkan hasil penelitian yang peneliti dapatkan, maka penerapan strategi Paradiplomasi dan 9 track diplomacy dalam mempublikasi pariwisata Indonesia telah dilakukan melalui tahap yang telah direncanakan melalui kerjasama dengan Pemerintah Daerah hingga pihak swasta untuk mengikuti berbagai event-event di Arab Saudi hingga Timur Tengah, sehingga memperluas pengetahuan masyarakat Arab Saudi tentang pariwisata Indonesia.
\end{abstract}

Kata Kunci : Indonesia-Arab Saudi, Peningkatan kunjungan wisatawan Arab Saudi ke Indonesia, Paradiplomasi, Multi Track Diplomacy.

\section{PENDAHULUAN}

Berawal dari tahun 2009, sektor pariwisata di Indonesia mulai menjadi pusat perhatian Pemerintah Indonsia karena mengalami peningkatan pada bidang ekonomi sehingga mulai diperhitungkan cara untuk meningkatkan pariwisata di Indonesia, menurut data tahun 2009 peningkatan devisa negara pada sektor pariwisata berada pada 


\section{Global Insight Journal}

posisi kegita diantara produksi minyak, minyak kelapa sawit dan gas bumi. ${ }^{1}$ Wisatawan mancanegara yang berkunjung ke Indonesia menurut data tahun 2014 berjumlah 9,4 juta jiwa, data wisatawan ini mengalami peningkatan pertumbuhan perekonomian $7,05 \%$ dari tahun-tahun sebelumnya. Keanekaragaman penduduk, kebudayaan, kuliner hingga wilayahnya menjadi pusat perhatian sekaligus menjadi daya tarik pada destinasi wisata Indonesia, keberagaman wilayah Indonesia yang terdiri 17.508 pulau yang memiliki iklim tropis, tetapi ada sekitar 6000 pulau tidak berpenghuni. ${ }^{2}$

Wisatawan Arab Saudi yang berkunjung ke Indonesia pada tahun 2014 berjumlah 151.454 orang, tahun 2015 mengalami peningkatan yang sangat drastis berjumlah 160.696 hingga tahun 2016 wisatawan Arab Saudi berjumlah 186.654 peningkatan 15.54\% pertumbuhan wisatawan Arab Saudi dari tahun 2014-2016. ${ }^{3}$ Berdasarkan data kunjungan wisatawan Arab Saudi yang diperoleh dari Kementerian Pariwiwsata, jumlah wisatawan Arab Saudi dari tahun 2014-2016 mengalami peningkatan yang signifikan sehingga membuat peneliti tertarik melakukan penelitian terhadap wisatawan Arab Saudi karena Negara Arab Saudi adalah salah satu negara di kawasan Timur Tengah yang tergabung dalam negara kawasan GCC.

Arab Saudi yang berpenduduk 28,83 juta orang dengan gross domestic product (GDP) sebesar USD 756 miliar. ${ }^{4}$ Pada tahun 2013, jumlah outbound Saudi Arabia tumbuh sebesar $12 \%$ dengan total perjalanan 18 juta. ${ }^{5}$ Sebagai salah satu negara kaya di kawasan Timur Tengah, Arab Saudi pada tahun 2014 merupakan penyumbang 147,074 atau 87,33\% dari jumlah total 216.313 kunjungan wisman asal Timur Tengah (Arab Saudi, UEA, Mesir, Bahrain dan Timur Tengah lainnya) dengan pengeluaran (spending) sebesar USD 1.444.82 tahun 2015, tahun 2016 USD 1.918.18. Arab Saudi juga menempati peringkat pertama kunjungan wisatawan mancanegara di kawasan imur Tengah yang datang ke Indonesia artinya Arab Saudi sebagai negara penyumbang devisa terbesar untuk Indonesia dari kawasan Timur Tengah. Arab Saudi juga

${ }^{1}$ Ranking Devisa Pariwisata Terhadap Komoditas Ekspor Lainnya tahun 2004-2009. Kementerian Kebudayaan dan Pariwisata RI. Diakses pada 15 April 2017.

2 Indonesia. The World Factbook. CIA. 2006. Diakses tanggal 15 April 2017.

${ }^{3}$ Ditjen Imigrasi dan BPS (diolah kembali oleh Asdep Litbangjakpar Kemenpar). http://www.kemenpar.go.id. Diakses pada 15 April 2017

${ }^{4}$ The World Bank, 2013, http://data.worldbank.org/country/saudi-arabia. Diakses pada tanggal 20 Juli 2017

${ }^{5}$ Euromonitor International, Beauty and Personal Care in Indonesia, 2013 diakses tanggal 20 Juli 2017. 


\section{Global Insight Journal}

menempati urutan ke-14 dari jumlah kunjungan wisatawan mancanegara menurut pintu masuk dan kebangsaan pada tahun 2016.

\section{KERANGKA TEORITIS}

\section{Paradiplomasi}

Paradiplomasi secara relatif masih merupakan fenomena baru bagi aktivitas pemerintahan di Indonesia. Paradiplomasi mengacu pada perilaku dan kapasitas untuk melakukan hubungan luar negeri dengan pihak asing yang dilakukan oleh entitas 'sub-state', atau pemerintah regional/pemda, dalam rangka kepentingan mereka secara spesifik. ${ }^{6}$ Maksudnya dalam hal ini adalah Pemerintah Daerah dapat melakukan hubungan kerja sama dengan pihak asing hanya sebatas kerja sama untuk meningkatkan perekonomian di daerahnya dengan meningkatkan potensi pariwisata, pendidikan, kesehatan tidak bisa menjalin hubungan dengan pihak asing yang sifatnya diplomatik resmi yang hanya dapat dilakukan oleh Pemerintah Pusat.

\section{Multi Track Diplomacy}

Keseluruhan dari 9 (Sembilan) track dalam 'multi-track diplomacy' itu adalah sebagai berikut:

DR Louise Diamond dam John W. McDonald mengkategorikan tingkatantingkatan dalam Multi-Track Diplomacy menjadi 9 (sembilan) jalur/track, yaitu: Government (Pemerintah), Non-Government (Non-Pemerintah), Business (Perdagangan), Private Citizen (Warga Negara), Research/Training/Education (Pendidikan/Penelitian/Pengembangan), Peace Activism (Advokasi), Religion (Agama), Funding (Pendanaan) dan Media. ${ }^{7}$ Upaya diplomasi yang dilakukan oleh Indonesia dalam meningkatkan pariwisata Indonesia di dunia internasional

\footnotetext{
${ }^{6}$ Wolff, Stefan, 'Paradiplomacy: Scope, Opportunities and Challenges', hal. 1-2 dan 13, University of Nottingham, 2009. Dikutip dari Takdir Ali Mukti dalam buku Paradiplomacy, hal.2. 2013.

${ }^{7}$ C.P.F Luhulima. Peranan Diplomasi Multi-Track dalam Penyelesaian Sengketa laut Cina Selatan; Upaya dan Tantangan. Jurnal Ilmiah Hubungan Internasional, 5 (2). Hal. 75. Dikutip dari JOM FISIP Vol.3, No.1, Februari 2016.
} 


\section{Global Insight Journal}

ini merupakan cara diplomasi yang melibatkan beberapa aspek Multi Track Diplomacy.

\section{Diplomasi Kebudayaan}

Penggunaan teori Diplomasi Kebudayaan karena Diplomasi Kebudayaan merupakan bagian dari Soft Diplomacy yang dapat diartikan sebagai usaha suatu negara untuk memperjuangkan kepentingan nasionalnya melalui dimensi kebudayaan. $^{8}$ Diplomasi Kebudayaan mencakup kesenian, pariwisata, olahraga, tradisi, teknologi hingga pertukaran ahli dan lain sebagainya. ${ }^{9}$ Dari penjelasan tersebut dapat dipahami bahwa diplomasi yang dilakukan dalam upaya mencapai kepentingan nasional di bidang pariwisata juga merupakan bagian dari diplomasi kebudayaan yang merupakan bentuk dari soft diplomacy.

Karena Pemerintah Arab Saudi adalah salah satu aktor internasional yang maju dalam peningkatan pada sektor ekonomi, sektor pariwisata, sektor industrialisasi, sektor pendidikan sehingga memberikan motivasi untuk Pemerintah Indonesia dibawah kepemimpinan Presiden Joko Widodo untuk berperan aktif meningkatkan pariwisata Indonesia dengan meningkatkan kunjungan wisatawan Arab Saudi ke Indonesia melalui implementasi diplomasi kebudayaan secara baik dan benar agar dapat meningkatkan sektor pariwisata yang menjadi penyumbang devisa terbesar setelah minyak dan gas bumi.

\section{Konsep Kepariwisataan}

Konsep pariwisata ini merupakan strategi pembangunan pariwisata yang difokuskan pada kondisi negaranya dimana kegiatan-kegiatannya akan mengikutsertakan negara-negara lain sehingga diperoleh suatu potensi atau daya tarik bersama yang tentunya jauh lebih besar. Terjalinnya kerjasama antar keduanya dapat mempertemukan visi-visi tersebut, dimana pada akhirnya Indonesia dan Arab Saudi, berupaya untuk meningkatkan arus kunjungan wisatawan mancanegara ke Indonesia. Oleh karena itu dengan adanya kerjasama antar kedua pihak, diharapkan memberi peluang yang positif bagi pencapaian

\footnotetext{
${ }^{8}$ Tulus, Warsito dan Wahyuni Kartikasari, Diplomasi Kebudayaan, Yogyakarta:Ombak, hal.4, 2007.

${ }^{9}$ Ibid, hal. 5.
} 


\section{Global Insight Journal}

kepentingan-kepentingan tersebut terutama dalam pariwisata internasional yang hingga kini tengah meningkat pesat. James J. Spillane mengatakan,

"Pariwisata Internasional, disamping jelas menyangkut manfaat pendidikan, kebudayaan dan sosial juga mempunyai arti penting dari segi ekonomi, diantaranya penerimaan devisa. Banyak negara berpendapat bahwa pariwisata internasional merupakan salah satu faktor penting dalam ekonomi nasionalnya" ${ }^{, 10}$

\section{Pembahasan}

\section{Strategi Pemerintah Indonesia dalam hal ini Kementerian Pariwisata melalui konsep Paradiplomasi dan Multi Track Diplomacy}

1. KBRI Riyadh \& KJRI Jeddah

2. Koordinasi dengan Kementerian Luar Negeri

3. Kementerian Pariwisata bekerjasama dengan Pemerintahan Daerah, Industri Pariwisata, PCO, Tim Kesenian dari Indonesia dan Tim Kesenian Diaspora

4. Kegiatan Kementerian Pariwisata Pameran, Sales Mission, Familiarization Trip, Festival

5. Analisa Strategi Kementerian Pariwisata Dalam Paradiplomasi dan Multi Track Diplomacy (track 1 government, track 2 non-government, track 3 bisnis, track 4 warga negara, track 5 penelitian, pelatihan dan pendidikan, track 9 media)

6. Meningkatkan kunjungan wisatawan Arab Saudi

\section{Paradiplomasi}

Sektor Pariwisata sedang menjadi tranding topic pada era saat ini karena menuntut Pemerintah Daerah harus kreatif dan inovatif dalam membangun dan mengembangkan potensi daerahnya untuk menarik wisatawan asing datang ke daerah tersebut sehingga dapat meningkatkan sirkulasi perekonomian di suatu daerah.

Dalam paradiplomasi ini pemerintah daerah yang berperan dalam kegiatan Kementerian Pariwisata adalah Dinas Budaya dan Pariwisata Nusa Tenggara Barat (NTB) dan Dewan Perwakilan Rakyat Daerah (DPRD) Provinsi Nusa Tenggara Barat (NTB). Karena Nusa Tenggara Barat (NTB) memenangkan Lombok dalam event World Halal Travel Summit \& Exhibition di Abu Dhabi, sehingga perlu untuk Pemerintah

\footnotetext{
${ }^{10}$ Jarnes J. Spillane, Ekonomi Pariwisata, Sejarah dan Prospeknya, Yogyakarta: Kanisius, hal.23, 1987.
} 


\section{Global Insight Journal}

Indonesia dalam hal ini Kementerian Pariwisata mempromosikan Lombok kepada masyarakat Timur Tengah, khususnya Arab Saudi. Dengan peran Dinas Budaya dan Pariwisata Nusa Tenggara Barat (NTB) dan Dewan Perwakilan Rakyat Daerah (DPRD) Provinsi Nusa Tenggara Barat (NTB) bergabung dalam kegiatan Kementerian Pariwisata di Aras Saudi sehingga dapat memberikan informasi secara terperinci kepada industri travel Arab Saudi, sehingga dapat saling berinteraksi dan bertukar informasi antara Pemerintah Daerah NTB dengan Industri Pariwisata Arab Saudi.

\section{Dari Delegasi Nusa Tenggara Barat (NTB), mengusulkan sejumlah hal berikut: ${ }^{11}$}

1) mengusulkan untuk membuat Peraturan Daerah (Perda) tentang Halal Tourism

2) Permohonan dukungan agar Provinsi Nusa Tenggara Barat (NTB) juga dipromosikan dikalangan masyarakat Arab Saudi, mengingat Provinsi ini memiliki daya tarik wisata yang cocok untuk pasar Timur Tengah, mulai dari panorama alam, makanan halal, jumlah penduduknya yang mayoritas muslim, serta jaraknya yang sangat dekat dengan Bali yang merupakan destinasi yang sangat terklenal dikalangan turis mancanegara, termasuk yang berasal dari Arab Saudi.

\section{Multi Track Diplomacy}

\section{Track 1 Government/Pemerintah Pusat}

\section{a. Kementerian Luar Negeri, KBRI Riyadh, KJRI Jeddah}

Hubungan diplomatik Indonesia-Arab Saudi bermula karena terkait dengan usaha rakyat Indonesia untuk mendapatkan kemerdekaan yang selalu memperoleh dukungan dan simpati dari negara-negara di Timur Tengah khususnya Arab Saudi. Warga Arab Saudi selalu menjadikan jemaah haji asal Indonesia sebagai cerita menarik yang sering dibicarakan terkait perjuangan serta usaha bangsa Indonesia dalam melepaskan diri dari penjajahan dan mendapatkan kemerdekaannya. ${ }^{12}$

\footnotetext{
${ }^{11}$ Kementerian Pariwisata, "Laporan Pelaksanaan Kegiatan Pemasaran Pariwisata Indonesia Tahun 2015”, Jakarta: Kemenpar, hal. 2-3, 2015.

12 Putuhena Shaleh, "Historiografi Haji Indonesia", Yogyakarta: LKiS, hal. 22, 2007. Dikutip dari Faiz Resha Majid, "Dinamika Penyelenggaraan Ibadah Haji Indonesia di Arab Saudi”. Diakses pada tanggak 18 Maret 2017.
} 


\section{Global Insight Journal}

Kedutaan Besar Republik Indonesia (KBRIIndustrial gathering ${ }^{13}$ yaitu pertemuan yang dilaksanakan di Wisma Nusantara KJRI Jeddah. Kegiatan ini dihadiri oleh 6 Konsul Jenderal yaitu dari Negara Filipina, Jepang, Korea Selatan, Palestina, Pakistan, Brunei dan India. Selain itu, kegiatan ini juga dihadiri oleh undangan yang berasal dari kalangan pengusaha, birokrat, para manajer airlines dan jurnalis serta undangan yang lain. Pertemuan ini membahas tentang peraturan Bebas Visa Kunjungan Warga Arab Saudi dan didukung dengan banyak alternative penerbangan dari Timur Tengah ke Indonesia (Qatar Airways, Emirates Airlines, Saudi Airlines dan Jodan Air yang akan terbang direct menuju Indonesia), serta membahas kemenangan Lombok di Nusa Tenggara Barat (NTB) sebagai destinasi halal pada ajang World Halal Award sehingga membuka peluang bagi Indonesia untuk menarik lebih banyak lagi wisatawan asal Arab Saudi untuk berlibur ke Indonesia.

\section{b. Kementerian Pariwisata ${ }^{14}$}

Peran Pemerintah Indonesia dalam hal ini Kementerian Pariwisata diwakili oleh Asdep Pengembangan Pasar Eropa, Timur tengah, Amerika dan Afrika, Kepala Bidang Promosi Pasar Timur Tengah, Auditor Muda Inspektorat Kementerian Pariwisata, Staf Asdep Pengembangan Pasar Eropa, Timur Tengah, Amerika dan Afrika.

Kementerian Pariwisata kerjasama dengan tim Disbudpar NTB, DPRD NTB Melakukan pertemuan ke KBRI Riyadh untuk menyampaikan informasi, dalam beberapa hal, diantaranya:

1. Peraturan Presiden tentang fasilitas Bebas Visa Kunjungan, dimana salah satu negara yang mendapatkan fasilitas ini adalah Arab Saudi, yang diharapkan akan menambah kemudahan bagi Warga Negara Arab Saudi untuk berkunjung ke Indonesia

2. Usulan pembentukan VITO (Visit Indonesia Tourism Officer) khusus Arab Saudi (selain VITO Timur Tengah), mengingat Arab Saudi memiliki karakteristik yang sangat berbeda dengan Negara Timur Tengah yang lain

\footnotetext{
${ }^{13}$ Ibid, hal 5.

${ }^{14}$ Kementerian Pariwisata, "Laporan Pelaksanaan Kegiatan Pemasaran Pariwisata Indonesia Tahun 2015”, Jakarta:Kemenpar, 2015.
} 


\section{Global Insight Journal}

3. Perkembangan jumlah wisatawan asal Arab Saudi tahun 2015 berjumlah 10.540, naik 3,22\% dibanding periode yang sama tahun 2014

4. Undangan Famtrip bagis media-media di Arab Saudi, dengan harapan melalui pemberitaan dari media yang menjadi peserta famtrip, akan memberikan informasi pariwisata Indonesia yang lebih mendalam bagis masyarakat setempat

5. Kemenangan Lombok dalam event World halal Travel Summit \& Exhibition di Abu Dhabi, sehingga perlu untuk mempromosikan Lombok kepada masyarakat Timur Tengah khusunya Arab Saudi.

\section{Track 2 Non-Government}

Non-Pemerintah ini berfungsi untuk menunjang, membantu dan melancarkan tugas Pemerintah Indonesia yang sudah membuka jalur diplomatik dengan Arab Saudi, sehingga memudahkan aktor-aktor non-pemerintah untuk melakukan kegiatan di Arab Saudi.

\section{a. PCO dari PT. Mega Citra Permata ${ }^{15}$}

1) Mempresentasikan step by step kepada Asdep ETTAA Kementerian Pariwisata untuk keberlangsungan kegiatan Kementerian Pariwisata yang akan diselenggarakan di Arab Saudi

2) Koordinasi dengan organizers Arab Saudi untuk pembayaran sewa ruang kegiatan Kementerian Pariwisata

3) Pengurusan biaya perjalanan selama ke Arab Saudi berangkat hingga kembali ke Indonesia

4) Koordinasi dengan Asdep ETTAA tentang persiapan bahan-bahan promosi yang akan didistributorkan pada saat kegiatan Kementerian Pariwisata di Arab Saudi

\section{b. Tim Kesenian dari Sanggar Tari Sanggar Tari Blitar Rose Dancer Jenis tarian tradisional Indonesia antara lain: ${ }^{16}$}

\footnotetext{
${ }^{15}$ Kementerian Pariwisata, "Laporan Pelaksanaan Kegiatan Pemasaran Pariwisata Indonesia Tahun 2015 ,' Jakarta: Kemenpar, 2015, hal 1-2.
} 
1) Sesi 1: Sensation Nusantara Dance yakni kolaborasi tari Saman (Aceh), tari Merak (Bali), tari Lenso (Maluku)

2) Sesi 2: Beautiful of Indonesian Dance yakni kolaborasi tari Piring (Padang), tari Dolanan (Jateng) dan Sesundaan (Bandung)

3) Sesi 3: Wonderful Indonesia Dance yakni kolaborasi tari Jaipong (Jabar) tari Perang (Kalimantan) dan tari Topeng Betawi (Jakarta)

4) Secara keseluruhan kesenian dari Indonesia yang dipertunjukkan Pemerintah Indonesia dalam kegiatan Kementerian Pariwisata di Arab Saudi hingga Kawasan Timur Tengah yaitu Bajidor Kahot (Jawa Barat), Njot-Njotan (Jakarta/Betawi), Ngepak Enggang (Kalimantan Timur), Tari Piring (Sumatera Barat), Tari Saman (Aceh), Tari Cendrawasih (Bali), Tari Rampak Pemudi, Tari Cinta Indonesia, Pertunjukan Angklung, Pertunjukan Silat

\section{Track 3 Bisnis Melalui Perdagangan}

Pemerintah melibatkan sektor bisnis, karena sektor bisnis dianggap dapat membantu keberhasilan tercapainya kepentingan Negara. ${ }^{17}$ Berikut bisnis-bisnis yang terlibat dalam upaya Indonesia mempromosikan pariwisata Indonesia:

Paket-paket wisata yang dipromosikan dalam Pameran di Arab Saudi yaitu: ${ }^{18}$

a) Produk Jakarta : Pulau Seribu, Dufan Ancol, Kidzania dan Shopping

b) Produk Bandung : Trans Studio, factory outlet

c) Produk Bali : Safari Park

d) Produk Lombok : Restoran makanan Arab/Kuliner Halal

\section{Industri Pariwisata yang mempromosikan paket wisata Indonesia: ${ }^{19}$}

1) Sun Island Bali Group

2) Discovery Kartika Plaza Hotel

\footnotetext{
${ }^{16}$ Wawancara dengan Staff Kemenpar Asdep ETTAA, Jakarta, 3 Agustus 2017.

${ }^{17}$ Indrawati, "Peran Sektor Bisnis Dalam Penandatanganan Voluntary Partnership Agreement On Forest Law Enforcement Governance And Trade (Vpa-Flegt) antara Indonesia dan Uni Eropa”, Jakarta: Global Insight Journal, 2016 hal. 40

${ }^{18}$ Kementerian Pariwisata, "Laporan Pelaksanaan Kegiatan Pemasaran Pariwisata Indonesia Tahun 2015”, Jakarta: Kemenpar, 2015, hal 10.

${ }^{19}$ Kementerian Pariwisata, "Nota Dinas Kegiatan Sales Mission Saudi Arabia 2016", Jakarta: Kemenpar, 2015, hal 10 .
} 


\section{Global Insight Journal}

3) Marintur Indonesia

4) Citra Netratama Tours and Travel

5) Nira Travel Indonesia

6) Fokus Indonesia Tours

7) ESQ Halal Holidays

8) Lisa Tours and Travel

9) Jayakarta Hotel and Resort

10) Accord Hotels Group

Pemerintah Indonesia dengan Industri Pariwisata mengikuti Pameran yang diadakan di Arab Saudi, diantaranya : ${ }^{20}$

\section{a. Jeddah International Travel and Tourism Exhibition (JTTX)}

Adalah kegiatan pameran pariwisata internasional yang bersifat $\mathrm{B}$ to $\mathrm{C}$ (Business to Customer) yang diikuti bukan hanya kalangan industri pariwisata, tetapi juga kalangan pemerintah dan asosiasi. Kementerian Pariwisata mengajak industri pariwisata, Travel Agent, Hotel, Tour Operator yang bertindak sebagai buyer dapat menjual paket wisata Indonesia langsung ke customer.

\section{b. Riyadh Travel Fair (RTF)}

Kegiatan ini adalah ajang untuk mempromosikan destinasi dan produkproduk wisata Indonesia secara utuh sehingga meningkatkan jumlah wisatawan Timur Tengah khususnya Arab Saudi. Pada umumnya yang berkunjung ke Indonesia Riyadh Travel Fair (RTF) adalah kegiatan Bursa Pariwisata Internasional terkemuka di Timur Tengah yang diadakan di Riyadh, Arab Saudi.

\section{c. Misi Penjualan/Sales Mission}

Adalah kegiatan bisnis antara Saller dari Indonesia bertemu dengan Buyers dari wilayah timur Kawasan Arab Saudi dilaksanakan di kota Damman. Kegiatan ini dilakukan Asisten Deputi Pengembangan Pasar Eropa, Timteng, Amerika dan Afrika Kementerian Pariwisata, kerjasama dengan seller di Indonesia untuk memasarkan dan menjual produk wisata

\footnotetext{
${ }^{20}$ Wawancara dengan Staff Kemenpar Asdep ETTAA, Jakarta, 3 Agustus 2017.
} 
Indonesia. Seller Indonesia diantaranya Sun Island Bali Group, Hotel Discovery Kartika Plaza, Hotel Borobudur Jakarta, Samabe Bali Suites \& Villas, Accor Hotels Group, Fokus Indonesia Tours, Kemtravel, Marintur Indonesia, Nira Travel dan Intercontinental Bali Resort.

\section{d. Festival}

Adalah kolaborasi antara kegiatan pameran tunggal dengan Festival Indonesia di Mancanegara yang merupakan kerjasama promosi antara Kementerian Pariwisata dengan Al Rais Tour \& Holiday, salah satu agen perjalanan (travel agent) sekaligus wholesellers terkemuka di Uni Emirat Arab

\section{Track 4 Warga Negara}

Track 4 menggunakan Warga Negara disini dimaksudkan adalah melibatkan Warga Negara Indonesia seperti Putra-Putri Pariwisata Nusantara dalam kegiatan yang dilakukan Pemerintah Indonesia dalam hal ini Kementerian Pariwisata terlibat dalam aktivitas mempromosikan destinasi pariwisata Indonesia di Arab Saudi hingga Kawasan Timur Tengah. Kementerian Pariwisata mengajak Putra-Putri Pariwisata Nusantara ${ }^{21}$ menjadi motivator pariwisata di daerah masing-masing. Selain itu, mereka juga bertugas mendorong peningkatan pelayanan promosi pariwisata, memberikan wawasan mengenai promosi pariwisata Nusantara, dengan memiliki pemahaman mengenai peluang dan investasi pariwisata Nusantara sehingga dapat ikut serta promosikan pesona Indonesia ke seluruh dunia. Menteri Pariwisata Arief Yahya juga mengatakan bahwa Seorang Duta Pariwisata sangat penting mempromosikan destinasi wisata dalam mengembangkan industri pariwisata, kemajuan industri Pariwisata Indonesia salah satunya dari peran para Putra Putri Pariwisata Nusantara harus memiliki misi yang sama dengan Kementerian Pariwisata yaitu mempromosikan Pariwisata Indonesia.

\section{Track 5 Penelitian, Pelatihan dan Pendidikan}

21 Dikutip dari https://www.cnnindonesia.com/gaya-hidup/20170507150527-307-212927/ini-dia-sosokduta-pariwisata-nusantara-2017/. Diakses pada tanggal 7 September 2017. 


\section{Global Insight Journal}

Penelitian, Pelatihan dan Pendidikan dalam hal ini sekolah tinggi dibawah naungan Kementerian Pariwisata, seperti STP NHI Bandung ${ }^{22}$ Berdasarkan data hasil wawancara dengan Staf Kementerian Pariwisata Asdep ETTAA Ratih Swardanie ${ }^{23}$ bahwa salah satu kegiatan Penelitian, Pelatihan dan Pendidikan yaitu:

a) Telah ditandatangani Letter of Intent antara STP Bandung dan King Abdullah University-Institute of Tourism. Diharapkan pengajar STP Bandung dapat mengajar di Arab Saudi

b) Peluang bagi tenaga kerja pariwisata Indonesia untuk bekerja dibanyak hotel yang sedang dibangun di Arab Saudi

c) Kemudian menurut Menteri Pariwisata Arief Yahya lulusan STP Bandung 40\% bekerja di luar negeri, Akpar Negeri Medan 30\% direkrut perusahaan asing, sisanya seperti STP Nusa Dua Bali, Poltekpar Negeri Makassar, Poltekpar Negeri Palembang, Poltekpar Negeri Lombok diserap habis di sektor pariwisata.

\section{Track 9 Media}

Track 9 Medi yaitu Kementerian Pariwisata mengadakan kegiatan kegiatan Familiarization Trip (FamTrip) dengan peserta dari pihak media dalam Peraturan Menparekraf No.5 Tahun $2014^{24}$ tentang Kegiatan Perjalanan Wisata Pengenalan: Adalah membawa orang/sekelompok orang, untuk mengunjungi destinasi dan meningkatkan citra kepariwisataan Indonesia serta meningkatkan peluang dan kerjasama baru antara peserta dengan Industri pariwisata yang ada di Indonesia, tujuannya untuk terwujudnya paket wisata baru yang dibuat oleh peserta dari penyedia bisnis dan diseminasi informasi pariwisata melaui pembuat opini. Famtrip (Familiarization Trip) suatu perjalanan yang diadakan untuk lebih mengenal produk wisata ataupun destinasi, bagi media-media di Arab Saudi, dengan harapan melalui pemberitaan dari media yang menjadi peserta dalam kegiatan famtrip ini, akan

\footnotetext{
${ }^{22}$ Dikutip dari http://sbmstapp.kemenpar.go.id/portal/lokasi. Diakses pada tanggal 1 September 2017.

${ }^{23}$ Wawancara dengan Staff Kemenpar Asdep ETTAA, Jakarta, 3 Agustus 2017.

24 Peraturan Menparekraf No. 5 Tahun 2014 tentang Pedoman Penyelenggara Perjalanan Wisata Pengenalan, hal. 7, 2014. Dikutip dari http://peraturan.go.id/permen/kemenparekraf-nomor-5-tahun2014.html. Diakses pada tanggal 7 September 2017.
} 


\section{Global Insight Journal}

memberikan informasi pariwisata Indonesia yang lebih mendalam bagi masyarakat setempat

\section{Proses Pelaksanaan Famtrip ${ }^{25}$}

Pre :

1) Perekrutan Peserta : Koordinasi dengan KBRI, KJRI, VITO dan Media

2) Pengiriman Surat Undangan ke Peserta

3) Pengiriman dokumen famtrip : LOC, media application dan testimony

4) Koordinasi Dengan Dinas Pariwisata dan Instansi Terkait

On :

a) Mengunjungi destinasi

b) Melakukan peliputan

c) Melakukan bussiness gathering

d) Melakukan pendampingan

\section{Post :}

a. Pelaporan Kegiatan

b. Monitoring dan Evaluasi

\section{Peserta Famtrip}

1) Kementeria Pariwisata Media-cetak, elektronik dan blogger- Pengenalan destinasi dan citra dalam kegiatan wisata pengenalan Famtrip (Familiarization Trip) untuk memberikan informasi nyata kepada wisatawan mancanegara khusunya Arab Saudi tentang tujuan destinasi di Indonesia kepada aktor media yang menjadi peserta Famtrip, sehingga dapat mempublikasi pada media Arab Saudi mengenai paket wisata di Indonesia, untuk memberikan pengalaman nyata tentang destinasi di Indonesia, sehingga meningkatkan citra pariwisata Indonesia untuk mendapatkan kepercayaan publik atau masyarakat Arab Saudi. Dengan harapan melalui kegiatan Famtrip pemberitaan media Arab Saudi akan memberikan informasi Pariwisata Indonesia yang lebih mendalan bagi masyarakat setempat.

\footnotetext{
${ }^{25}$ Data Kementerian Pariwisata, Paparan Bimtek Famtrip Deputi BP3M, 2016.
} 


\section{Global Insight Journal}

Kunjungan kunjungan wisatawan mancanegara Arab Saudi sesuai dengan penelitian ini yaitu tahun 2004 hingga tahun 2016, dapat dilihat dari hasil (Growth) pertumbuhan kunjungan Arab Saudi, Angka pertumbuhan wisatawan Arab Saudi tahun 20014 hingga 2015 meningkat 9,26\%, kemudian dari 2015 hingga 2016 meningkat menjadi 16, 15\% hampir memasuki pertumbuhan 50\% peningkatan wisatawan Arab Saudi.

\section{Simpulan}

Berdasarkan hasil penelitian dan pembahasan yang sesuai tujuan penelitian yaitu mengetahui bagaimana strategi diplomasi Pemerintah Indonesia dalam meningkatkan kunjungan wisatawan Arab Saudi pada tahun 2014-2016, maka penulis dapat menarik kesimpulan sebagai berikut :

Strategi Diplomasi yang digunakan Pemerintah Indonesia melalui kegiatan yang dilakukan Kementerian Pariwisata sudah berjalan dengan baik, hal ini didukung oleh Kementerian Pariwisata dalam menggunakan strategi 9 (sembilan) track diplomacy dengan menjalin kerjasama dengan setiap track diplomasi yaitu Government (Pemerintah), Non-Government (Non-Pemerintah), Business (Perdagangan), Private Citizen (Warga Negara), Research/Training/Education (Pendidikan/Penelitian/Pengembangan), Peace Activism (Advokasi), Religion (Agama), Funding (Pendanaan) dan Media kemudian mengikuti kegitan Pameran, Misi Penjualan (Sales Mission), Familiarization Trip (FamTrip) dan Festival yang diadakan di Arab Saudi, Indonesia mulai mengikutinya dari tahun 2014-2016 berjalan hingga 2017. Secara efektif menciptakan saling pengertian dalam meningkatkan informasi kepada wisatawan Arab Saudi ke Indonesia serta melaksanakan segala hal yang menyangkut peningkatan kunjungan wisatawan Arab Saudi. Dengan kegiatan tersebut dinilai dapat dengan mudah memberikan informasi jelas dan mudah dimengerti tentang pariwisata di Indonesia karena dapat bertatap muka dengan masyarakat Arab saudi.

Strategi yang digunakan Kementerian Pariwisata dalam meningkatkan kunjungan wisatawan Arab Saudi adalah menggunakan strategi multi track diplomacy yang lebih fokus pada track one pemerintah, track two non-pemerintah, track three bisnis, track four warga negara, track five penelitian/pelatihan/pendidikan, track nine media. Implementasi Pemerintah Indonesia cq Kementerian Pariwisata bekerja sama dengan 


\section{Global Insight Journal}

fokus track diplomasi dalam mempresentasikan pariwisata Indonesia di Arab Saudi sehingga terlihat hasil kinerjanya dari data-data dalam hasil penelitian.

Berdasarkan hasil penelitian yang penulis dapatkan, maka penerapan strategi diplomasi Pemerintah Indoensia dalam meningkatkan kunjungan wisatawan Arab Saudi telah dilakukan melalui tahap yang telah direncanakan dengan baik dilihat dari hasil kunjungan wisatawan Arab Saudi ke Indonesia tahun 2014 hingga 2016 mengalami peningkat dari tahun 2014 - 2015 peningkatan kunjungan wisatawan sebesar 9,26\% kemudian dari tahun 2015-2016 pertumbuhan wisatawan Arab Saudi dari 9,26\% meningkat 16,15\%, sehingga terlihat hasil kunjungan wisatawan Arab Saudi dari 20142016 meningkat didukung oleh data-data yang telah dipaparkan.

\section{Saran}

a. Terkait karakteristik wisatawan mancanegara Arab Saudi menyukai destinasi yang sejuk, menyukai resort-resort pribadi yang bisa menampung keluarga besar, makanan halal adalah suatu keharusan. Inilah potensi yang bisa dijaring Pemerintah Indonesia untuk menciptakan destinasi baru untuk menarik wisatawan Arab Saudi

b. Perbaikan infrastruktur, akomodasi hingga pelatihan SDM (sumber daya manusia) terkait kemampuan berbklahasa dan wisata ramah muslim.

\section{DAFTAR PUSTAKA}

\section{Buku :}

Barston, R.P, Modern Diplomacy, New York: Cet II, United States of America by Longman Inc., 1988.

Convelo G. Cevilla, Pengantar Metode Penelitian, Jakarta: Universitas Indonesia, 1993.

Eko, Agustinova Danu. Memahami metode Penelitian Kualitatif Teori \& Praktik. Yogyakarta: Calpulis, 2015.

Haryono, Endi dan Saptopo B. Ilkodar, Menulis Skripsi:Panduan Untuk Mahasiswa Ilmu Hubungan Internasional, Yogyakarta: Pustaka Pelajar Offset, Cet I 2005, Cetakan II, 2009.

Holsti, K.J, International Politics, A Framework for Analysis, Third Edition, New Delhi: Prentice Hlml of India, 1984. 


\section{Global Insight Journal}

Joseph, S. Nye, Jr., Soft Power: The Means to Success in World Politics, hal. X, New York: Public Affair, 2004.

Kountur, Ronny, Metode Penelitian, Jakarta: PT. Raya Grafindo Persada, 2004.

Mardalis, Metode Penelitian: Suatu Pendekatan Proposal, Jakarta: Bumi Aksara, 1999.

Mas'oed, Mohtar, Ilmu Hubungan Internasional:Disiplin dan Metodologi, Jakarta: LP3ES, 1990.

Moleong, Lexy, Metodologi Penelitian Kualitatif, Bandung: PT. remaja Rosdakarya, 2002.

Mukhtar, Metode Penelitian Deskriftif Kualitatif, Jakarta: GP Press Group, 2013.

Mukti, Takdir Ali, Paradiplomacy:Kerja Sama Luar Negeri Oleh Pemda Di Indonesia, Yogyakarta: The Phinisi Press Yogyakarta, 2013.

Palitilima, Hamid, Metode Penelitian Kualitatif, Bandung: Alfabeta, 2005.

Roy, S.L, Diplomasi, Jakarta: Rajawali Pers, 1991.

Ruslan, Rosady, Manajemen Publik Relations \& Media Komunikasi, Konsep \& Aplikasinya, Jakarta: PT. Rajagrafindo Persada, Cetakan Kesepuluh, 2010.

Singarimbun, Masri dan Sofian Effendi, Metode Penelitian Survey, Jakarta: LP3ES, 1998.

Soeratno, M.Ec, Dr dan Lincolin Arsyad, M.Sc, Drs, Metodologi Penelitian (Untuk Ekonomi \& Bisnis), Yogyakarta: UUP AMP YKPN, 1995.

Spillane, James J, Ekonomi Pariwisata:Sejarah dan Prospeknya, Yogyakarta,: Kanisius, 1994.

---------- Pariwisata Indonesia. Yogayakarta: Kanisius, 1994.

Ekonomi Pariwisata, Yogayakarta: Kanisius, 1987.

Sudarto, Metodelogi Penelitian Filsafat, Jakarta: Raja Grafindo, 2001.

Sugiyono, Metode Penelitian Kuantitatif, Kualitatif dan $R \& D$, Bandung: Alfabeta, 2009.

Suprayogo, Imam dan Tobroni, Metodologi Penelitian Sosial-Agama. Bandung: Remaja, 2001.

Sastradipoera, Komaruddin, Mencari Makna Dibalik Penulisan Skripsi, Tesis dan Disertasi. Bandung: Kappa-Sigma, 2005. 


\section{Global Insight Journal}

Warsito, Tulus dan Wahyuni Kartikasari, Diplomasi Kebudayaan, Konsep dan Relevansinya Bagi Negara Berkembang: Studi Kasus Indonesia, Yogyakarta: H, Penerbit Ombak, 2007.

Wehrenfennig, Daniel, Multi Track Diplomacy and Human Security, Human Security Journal Volume 7, Summer 2008.

\section{Jurnal :}

Anggria, Anggit, "Strategi Human Kevas.Co Dalam Mempublikasi Produk Fashion Melalui Media Sosial Instagram”, 2017.

Ariyanto, Pebri, "Strategi Singapore Tourism Board dalam Meningkatkan Kunjungan Wisatawan asal Indonesia ke Singapore tahun 2008”, 2014.

Dyah Ruslina Novika Sari, Fitri. "Strategi Diplomasi Publik dalam Meningkatkan Citra dan Budaya Indonesia dimata Dunia Internasional (Studi kasus : Seni tarian dayak kalimantan Timur)”, 2013.

Fardhio Rachman, Mohammad, "Strategi Pemerintahan Indonesia dalam Kerjasama Pariwisata dengan Turki Era Presiden Susilo Bambang Yudhoyono”, Agustus 2016.

Indrawati, "Peran Sektor Bisnis Dalam Penandatanganan Voluntary Partnership Agreement On Forest Law Enforcement Governance And Trade (Vpa-Flegt) antara Indonesia dan Uni Eropa", Global Insight Journal, Vol.01, No. 01, 2016

Indriasih, Gusti, "Diplomasi Indonesia melalui Kampanye Wonderful Indonesia dalam Meningkatkan Pariwisata Indonesia di Dunia Internasional tahun 2011-2015”, 2011.

Luhulima, C. P. F, “Peranan Diplomasi Multi-Track dalam Penyelesaian Sengketa laut Cina Selatan:Upaya dan Tantangan”, Jurnal Ilmiah Hubungan Internasional, 5 (2), Dikutip dari JOM FISIP Vol.3, No.1, Februari 2016.

Majid, Faiz Resha, "Dinamika Penyelenggaraan Ibadah Haji Indonesia di Arab Saudi”, Agustus 2015.

Ryani Wiradinata, Dhiny, "Kerjasama Pariwisata Indonesia-Cina dan Pengaruhnya Terhadap Peningkatan Kunjungan Wisatawan Cina ke Indonesia”, 2015. 


\section{Global Insight Journal}

\section{Undang-Undang}

Peraturan Menteri Pariwisata Republik Indonesia nomor 6 tahun 2015 tentang organinsasi kerja Kementrian Pariwisata.

“Undang-Undang Republik Indonesia No. 9 Tahun 1990 Tentang Kepariwisataan", dalam http://www.budpar.go.id/regulasi 2 September 2013.

Peraturan Menparekraf No.5 Tahun 2014.

\section{Dokumen :}

Data Kementerian Pariwisata, Paparan Bimtek Famtrip Deputi BP3M, 2016. (dalam bentuk power point)

Ditjen Imigrasi dan BPS (diolah kembali oleh Asdep Litbangjakpar Kemenpar), (Direktur Jendral Imigrasi dan Badan Pusat Statistik diolah kembali oleh Asisten Deputi Penelitian Kelembagaan Jakarta Pariwisata Kementerian Pariwisata).

Hadi, Andri, Bahan Seminar "Politik Luar Negeri Indonesia: Prospek dan tantangan dalam Era Globalisasi”, Dirjen IDP Separtemen luar Negeri Republik Indonesia, 2009.

Laporan Pelaksanaan Kegiatan Pemasaran Pariwisata Indonesia Tahun 2015, Jakarta, Kementerian Pariwisata, November 2015.

Laporan Nota Dinas Kegiatan Sales Mission Saudi Arabia 2016, Jakarta, Kementerian Pariwisata, April 2016.

Passenger Exit Survey Indonesia 2015, Data langsung dari tempat magang di Kementerian Pariwisata bagian ETTAA.

Pusdatin Kemenparekraf \& BPS (Pusat Data Indonesia Kementerian Pariwisata Ekonomi \& Kreatif dan Badan Pusat Statistik).

Renstra KBRI Riyadh 2015-2019

Wolff, Stefan, 'Paradiplomacy: Scope, Opportunities and Challenges', University of Nottingham, 2009.

\section{Wawancara :}




\section{Global Insight Journal}

Data langsung dari Staff Asisten Deputi Eropa, Timur Tengah, Amerika dan Afrika Ratih Swardanie Nur Jannah dan Muchlasin, selama peneliti melakukan magang di Kementerian Pariwisata pada Periode November 2016-Januari 2017

\section{Internet :}

Air Dewangga, Thanon, Asisten Deputi Bidang Pelaksanaan dan Pelapor Persidangan, Diplomasi melalui Soft Power, yang dipublikasi pada laman http;//www.setkab.go.id/artikel-6305-.html, diakses pada tanggal 15 April 2017.

Countries of the World by Area-No 16 Indonesia, diakses pada tanggal 15 April 2017.

Daftar tempat yang telah ditetapkan sebagai Situs Warisan Dunia, UNESCO, diakses pada tanggal 15 April 2017.

Daftar Representantif Warisan Budaya Takbendawi, UNESCO, diakses pada tanggal 15 April 2017.

Gulf Cooperation Council, dalam

http://inatrims.kemendag.go.id/id/product/detail/sistem-klasifikasi-gulfcooperation-council-gcc_840/?market=ar, diakses pada tanggal 20 juli 2017.

Perguruan tinggi pariwisata dibawah naungan Kementerian Pariwisata, dalam http://sbmstapp.kemenpar.go.id/portal/lokasi, diakses pada tanggal 1 September 2017.

Ditjen Imigrasi dan BPS (diolah kembali oleh Asdep Litbangjakpar Kemenpar). 


\section{Global Insigiht Journal}

http://www.kemenpar.go.id, diakses pada tanggal 15 April 2017.

Duta Pariwisata Indonesia, dalam https://www.cnnindonesia.com/gayahidup/20170507150527-307-212927/ini-dia-sosok-duta-pariwisata-nusantara-2017/, diakses pada tanggal 7 September 2017.

Euromonitor International, Beauty and Personal Care in Indonesia, 2013, diakses tanggal 20 Juli 2017.

Hijriyah, https://www.kemenag.go.id/, diakses pada tanggal 21 Maret 2017.

Indonesia, The World Factbook, CIA, 2006, diakses pada tanggal 15 April 2017.

(Inggris) Time for N. Maluku to become tourist destination, Antaranews, 8 Mei 2011, diakses pada tanggal 15 April 2017.

Kementerian Pariwisata, http://www.kemenpar.go.id/asp/index.asp, diakses pada tanggal 18 Maret 2017.

Kompas, 12 Maret 2010, diakses pada tanggal 20 April 2017.

Lewis, M. Paul(ed.), "Ethnologue-Languages of the World-Languages of Indonesia", Ethnologue: Languages of the World, edisi ke-16. Dallas, Tex.: SIL International. Versi daring. 2009, diakses pada tanggal 15 April 2017.

Ranking Devisa Pariwisata Terhadap Komoditas Ekspor Lainnya tahun 2004-2009, Kementerian Kebudayaan dan Pariwisata RI, diakses pada tanggal 15 April 2017.

Rikania, "Potensi Pariwisata", dalam http://rikania.multiply.com/Potensi_Pariwisata_files/44.htm, diakses pada tanggal 12 Juli 2017.

Selebriti peduli pariwisata dalam http://m.inilah.com/news/detail/2285134/menpar-arief-yahya-ajak-artis-pedulipariwisata, diakses pada tanggal 7 September 2017.

The World Bank, GDP per Capita Saudi Arabia (online) 2013, http://data.worldbank.org/country/saudi-arabia, diakses pada tanggal 20 Juli 2017.

What is Multi Track Diplomacy?, dalam http://www.imtd.org/index.php/about/84-about/131what-is-multi-track-diplomacy, diakses pada 18 Maret 2017 